\title{
Dental Health Status and Oral Health Care in Nursery School-Aged Children and their Parents Living in Poznan (Poland)
}

\author{
Karolina Gerreth ${ }^{\mathrm{a}}$ Timucin Ari ${ }^{\mathrm{b}}$ Wojciech Bednarz ${ }^{\mathrm{c}}$ Michal Nowicki ${ }^{\mathrm{d}}$ \\ Maria Borysewicz-Lewicka ${ }^{\mathrm{e}}$
}

\begin{abstract}
${ }^{a}$ Department of Risk Group Dentistry, Poznan University of Medical Sciences, Poznań, Poland; bivision of Orthodontics and Paediatric Dentistry, Western University Schulich School of Medicine and Dentistry, London, ON, Canada; ' Department of Periodontology, Wroclaw Medical University, Wrocław, Poland; ${ }^{d}$ Department of Histology and Embryology, Poznan University of Medical Sciences, Poznań, Poland; e Department of Pediatric Dentistry, Poznan University of Medical Sciences, Poznań, Poland
\end{abstract}

\section{Highlights of the Study}

- The findings of this study showed that children whose parents do not visit the dentist regularly have a higher incidence of dental caries.

- Some parents may be unaware that they should bring their child for regular dental check-ups starting from infancy.

- Medical professionals who treat children and their parents should inform them about the need for regular visits to the dentist.

\section{Keywords}

Dental health $\cdot$ Oral health care $\cdot$ Child $\cdot$ Mother $\cdot$ Father

\begin{abstract}
Objectives: The aim of this study was to evaluate the dental health status of nursery age children and parents. The use of dental services was assessed. Subjects and Methods: The study was performed in nursery schools located in Poznan, Western Poland. Clinical examination was carried out in 157 children (48.41\% males and $51.59 \%$ females), aged $10-42$ months. Dental health status (the number of teeth with caries, fillings and extracted) of their parents was determined on the basis of data obtained from a questionnaire. The questions also concerned information on child's and parents' dental check-ups and opinion on their predisposition to dental car-
\end{abstract}

\begin{tabular}{ll}
\hline KARGER & ( 2019 The Author(s) Karger \\
& Published by S. Karger AG, Basel Open ciccess \\
karger@karger.com & This is an Open Access article licensed under the Creative Commons \\
www.karger.com/mpp & $\begin{array}{l}\text { Attribution-NonCommercial-4.0 International License (CC BY-NC) } \\
\text { (http://www.karger.com/Services/OpenAccessLicense), applicable to } \\
\text { the online version of the article only. Usage and distribution for com- } \\
\text { mercial purposes requires written permission. }\end{array}$
\end{tabular}

ies. Results: Clinical examination revealed that $21.05 \%$ of boys and $18.51 \%$ of girls had dental caries. Most mothers had from 1 to 5 either carious and/or filled teeth (47.13\%) or extracted teeth due to carious process (61.15\%); the fathers' values were similar at 46.50 and $66.24 \%$, respectively. More mothers $(84.71 \%)$ than fathers $(72.62 \%)$ had regular dental check-ups $(p=0.02)$. The analysis of mother-father-child triads showed that when both parents visited the dentist regularly, more children were free of caries (56.68\%) in comparison to those with the disease (13.38\%; $p<0.001)$. Conclusions: This study showed that the dental health status, as well as oral care of nursery school children and their parents, is unsatisfactory. Therefore, there is a need to introduce an intensive dental educational program focusing on dental prophylaxis for nursery age children and their parents or caregivers.

(C) 2019 The Author(s)

Published by S. Karger AG, Basel

Karolina Gerreth

Department of Risk Group Dentistry, Chair of Pediatric Dentistry

Poznan University of Medical Sciences

70 Bukowska Street, PL-60-812 Poznan (Poland)

E-Mail karolinagerreth@ poczta.onet.pl 


\section{Introduction}

Dental caries is a chronic and multifactorial disease, and currently remains the most prevalent disorder of childhood [1]. There are numerous environmental risk factors responsible for carious process development. On the one hand, some components are related to behavioural determinants such as dietary and hygienic habits or transmission of germs between hosts $[2,3]$. On the other, individual factors like bacterial flora or composition of saliva and its flow rate are also important in this regard [4]. Needless to say, oral health care availability and socioeconomic status play a crucial role $[5,6]$. The family environment may be a factor that mediates the relationship between a child's oral health, oral health behaviours and social conditioning [7]. Oral health in children depends on their caregivers who are responsible for monitoring the child's eating habits, supervising and helping in the brushing of teeth, as well as accompanying them to regular dental visits [8]. In fact, each parental link factor, that is, parents' oral health behaviour, attitudes and knowledge, may be accepted as shaping the oral health behaviour of their children [9]. At present, the genetic component is also emphasized in literature as an important risk factor for dental disease [10, 11]. Wang et al. [10] reported that heritability of primary dentition dental caries was $>50 \%$. Streptococcus Mutans (MS) has been identified in $70-100 \%$ of the population as the principal etiological factor in the initiation of dental caries [12]. Research using molecular methods showed that mothers are more likely the primary source of bacterial infection [13]. MS may be transmitted, vertically from a caregiver to child through salivary contact. Furthermore, horizontal transmission might occur between other members of the family or children in day nurseries [14]. Several researchers are focused on the problem of transmission of MS $[15,16]$.

Dental caries may develop as soon as the first tooth erupts, and could have very severe consequences if a lesion is not treated. According to the definition by the American Academy of Pediatric Dentistry, disease in primary dentition (occurrence of one or more noncavitated or cavitated carious lesion, missing or filled due to caries tooth surfaces), in children younger than 71 months of age, is named Early Childhood Caries (ECC) [14]. Moreover, in children under the age of 3 years, the occurrence of smooth-surface caries is indicative of Severe-ECC [14]. The ECC has very quick progression, and in some cases the teeth are so severely affected by the disease process that in a very short time they become completely destroyed and need to be extracted [17]. Needless to say, untreated dental caries have a significant impact on the general health of patients $[17,18]$.

The aim of the present research was to evaluate: (1) dental health status of nursery age children and their parents, (2) use of dental services by examined population, (3) the differences between females and males concerning these issues.

\section{Methods}

\section{Study Group}

The study was performed between April and June 2014, in Poznan (Wielkopolska Province, Central-West Poland) on children who attended a unit of nursery schools composed of 4 subunits. This institution was chosen due to the fact that it is one of the biggest in the city.

Under local law on care of children under the age of 3, nurseries can be attended by children from the age of 20 weeks until the end of school year; when the child is 3 years old or if it is impossible or difficult to provide a child with pre-school education, up to the age of 4 [19]. The nursery provides care for up to $10 \mathrm{~h}$ a day.

This study was approved by the Ethics Committee of the Poznan University of Medical Sciences. Informed consent from children's parents and from the head teacher of the establishment, as well as teachers and staff from other divisions was also obtained.

The research consisted of dental examination of children, as well as a questionnaire study of their parents. During the school year 2013-2014, 321 children attended the aforementioned nursery schools. Before beginning the research, the main head teacher received information concerning the action from the researcher during the meeting. Then, she provided the staff with those details and teachers distributed the consent form to each parent along with a pamphlet explaining the purpose of the study at the nursery. There was a 15-days deadline for return of the forms to the staff of the nursery. Finally, 265 parents (recruitment rate $82.55 \%$ ) consented to their child's participation in the study, and 172 (53.58\%) parents answered the questions from the questionnaire.

\section{Clinical Examination of Children}

Each day nursery was visited by the researcher as many as $2-3$ times because some of the children were absent during the first day of examination. Three individuals were absent during each visit. In total, 262 children had dental check-ups.

The participation of each child in the study was voluntary. Clinical examination was carried out without any pharmacological preparation or physical restraints. The dentition was evaluated by a trained specialist in paediatric dentistry (K.G.), after calibration by another experienced specialist in paediatric dentistry (M.B.-L.). The intra-examiner agreement was assessed by another dental check-up in 10 children after 2 weeks, with a $\kappa$ of 1.00 . The procedures were performed in the classroom, which was separated from other children; however, the individuals were accompanied by teachers. Dental examination was run in an artificial lighting, with the use of a dental mirror and a probe, while the child was seated in the chair or the youngest ones on the teacher's lap, and the examiner stood in front of the chair. The dentist examined the children's teeth $1 \mathrm{~h}$ after the meal, and continued check-ups until the 
Table 1. Data concerning the number of children with caries as well as their parents with caries, fillings or extractions

\begin{tabular}{|c|c|c|c|c|}
\hline Teeth, $n$ & $\begin{array}{l}\text { Females, } \\
n(\%)\end{array}$ & $\begin{array}{l}\text { Males, } \\
n(\%)\end{array}$ & $\begin{array}{l}p \text { value } \\
\text { females vs. males }\end{array}$ & $\begin{array}{l}\text { Total, } \\
n(\%)\end{array}$ \\
\hline Children - total & $81(100.00)$ & $76(100.00)$ & & $157(100.00)$ \\
\hline $\begin{array}{l}\text { Teeth with caries }\left(\mathrm{dt}+\mathrm{d}_{\mathrm{i}} \mathrm{t}\right) \\
\quad 1-5\end{array}$ & $12(14.81)$ & $13(17.10)$ & ns & $25(15.93)$ \\
\hline $\begin{array}{l}\geq 6 \\
\text { None }\end{array}$ & $\begin{array}{c}3(3.70) \\
66(81.49)\end{array}$ & $\begin{array}{c}3(3.95) \\
60(78.95)\end{array}$ & $\begin{array}{l}\text { ns } \\
\text { ns }\end{array}$ & $\begin{array}{c}6(3.82) \\
126(80.25)\end{array}$ \\
\hline $\begin{array}{l}\text { Teeth with fillings } \\
\quad 1\end{array}$ & $1(1.23)$ & $0(0.00)$ & ns & $1(0.64)$ \\
\hline Parents - total & $157(100.00)$ & $157(100.00)$ & & $314(100.00)$ \\
\hline $\begin{array}{l}\text { Teeth with caries and/or filled } \\
1-5\end{array}$ & $74(47.13)$ & $73(46.50)$ & ns & $147(46.81)$ \\
\hline $\begin{array}{l}\geq 6 \\
\text { None } \\
\text { Do not know } \\
\text { No answer }\end{array}$ & $\begin{aligned} 67 & (42.67) \\
4 & (2.55) \\
8 & (5.10) \\
4 & (2.55)\end{aligned}$ & $\begin{aligned} 60 & (38.22) \\
3 & (1.91) \\
12 & (7.64) \\
9 & (5.73)\end{aligned}$ & $\begin{array}{l}\text { ns } \\
\text { ns } \\
\text { ns } \\
\text { ns }\end{array}$ & $\begin{array}{c}127(40.45) \\
7(2.23) \\
20(6.37) \\
13(4.14)\end{array}$ \\
\hline $\begin{array}{l}\text { Extracted teeth } \\
1-5\end{array}$ & $96(61.15)$ & $104(66.24)$ & ns & $200(63.69)$ \\
\hline $\begin{array}{l}\geq 6 \\
\text { None } \\
\text { Do not know } \\
\text { No answer }\end{array}$ & $\begin{array}{c}5(3.18) \\
54(34.39) \\
2(1.28) \\
0(0.00)\end{array}$ & $\begin{array}{c}4(2.55) \\
39(24.84) \\
7(4.46) \\
3(1.91)\end{array}$ & $\begin{array}{l}\text { ns } \\
\text { ns } \\
\text { ns } \\
\text { ns }\end{array}$ & $\begin{array}{c}9(2.87) \\
93(29.62) \\
9(2.87) \\
3(0.95)\end{array}$ \\
\hline
\end{tabular}

afternoon. The children's teeth were inspected wet without previous professional cleaning or drying. Each surface (except the interproximal surface where there was no access) of all erupted primary teeth was evaluated. The examination was primarily visual and a probe was used to confirm a carious lesion when it was found. Each tooth was assessed and scored as sound, decayed (dt) or filled (ft). The scoring system, for each surface of the tooth, was as follows: $0=$ no caries, $1=$ white spot lesion, $2=$ caries, $3=$ filling. Finally, on the basis of clinical examination, the number of teeth with white spot lesions $\left(\mathrm{d}_{\mathrm{i}} \mathrm{t}\right.$, initial carious lesion), the number of teeth with carious cavities $(\mathrm{dt})$ and those filled $(\mathrm{ft})$ were assessed. A tooth was considered carious when there was a white spot lesion or a carious cavity.

According to the literature, the white spot lesions were included in caries diagnosis $[17,20]$. Such changes are important, since they indicate caries and are prevalent within the child's teeth in the first years of life. When there was difficulty in distinguishing white spots from other defects (e.g., enamel hypomineralization), the tooth was assessed as sound.

\section{Sociomedical Study of Parents}

The questionnaire, in Polish, was distributed to parents by teachers at the nursery schools and filled out at home. Participation in the study was voluntary and full confidentiality of the collected data was provided to all study subjects. Close-ended questions of the questionnaire for parents concerned social characteristics such as: the age of mother and father, number of teeth with carious cavities and/or with fillings as well as those extracted, reg- ular check-ups at the dental surgery, opinion on their predisposition to dental caries and relationship of the person completing the questionnaire to the child. Participants were also asked if their child had ever been examined by a dentist. The questions with possible answers are presented in Tables 1 and 2. The information in the questionnaire concerned both parents; the form could be filled by both parents or one of them after consultation with the other. We evaluated the dental health status of the parents on the basis of their self-assessment, using the information they provided in the questionnaires. This has also been done in other studies [21, 22].

The analysis did not take into account questionnaires where there were missing answers to $>3$ questions or those without the child's personal data (name of the child). The final analysis dealt with the data from 157 participants, including parents of 81 (51.59\%) girls and 76 (48.41\%) boys.

\section{Statistical Analysis}

The difference test between 2 proportions between females and males (i.e., mothers and fathers, girls and boys) and the Statistica version 10 (Stat-Soft company) was used for the analysis of the following: the differences in the number of teeth with caries and/or filled teeth, extracted teeth, the frequency of dental visits, susceptibility of teeth to caries and a child's attendance at dental checkups. The same statistical tools were adopted for analysis concerning the differences between mother-father-child triads in relation to the frequency of parental visits to the dentist and occurrence of dental caries in the child. The assumed level of statistical significance was $p<0.05$. 
Table 2. Information on dental check-ups of children and systematic visits by parents to the dental clinic, as well as their opinion on susceptibility to dental caries

\begin{tabular}{|c|c|c|c|c|}
\hline $\begin{array}{l}\text { Survey questions and response } \\
\text { options }\end{array}$ & $\begin{array}{l}\text { Females, } \\
n(\%)\end{array}$ & $\begin{array}{l}\text { Males, } \\
n(\%)\end{array}$ & $\begin{array}{l}p \text { value } \\
\text { females vs. males }\end{array}$ & $\begin{array}{l}\text { Total, } \\
n(\%)\end{array}$ \\
\hline Children - total & $81(100.00)$ & $76(100.00)$ & & $157(100.00)$ \\
\hline \multicolumn{5}{|c|}{ Has the child ever been examined by a dentist at a dental clinic? } \\
\hline Yes & $31(38.27)$ & $39(51.32)$ & ns & $70(44.58)$ \\
\hline No & $50(61.73)$ & $37(48.68)$ & ns & $87(55.42)$ \\
\hline Parents - total & $157(100.00)$ & $157(100.00)$ & & $314(100.00)$ \\
\hline \multicolumn{5}{|c|}{ Does mother/father have regular dental check-ups at a dental clinic? } \\
\hline Yes & $133(84.71)$ & $114(72.62)$ & $0.02 *$ & $247(78.66)$ \\
\hline No & $23(14.65)$ & $38(24.20)$ & ns & $61(19.43)$ \\
\hline No answer & $1(0.64)$ & $5(3.18)$ & ns & $6(1.91)$ \\
\hline \multicolumn{5}{|c|}{ Does mother/father have teeth prone to caries ("weak teeth")? } \\
\hline Yes & $60(38.22)$ & $44(28.02)$ & ns & $104(33.12)$ \\
\hline No & $77(49.04)$ & $83(52.87)$ & ns & $160(50.95)$ \\
\hline Do not know & $19(12.10)$ & $24(15.29)$ & ns & $43(13.70)$ \\
\hline No answer & $1(0.64)$ & $6(3.82)$ & ns & $7(2.23)$ \\
\hline
\end{tabular}

ns, not significant $(p>0.05)$. ${ }^{*}$ Statistically significant $p$ value $(p<0.05)$.

\section{Results}

Among 321 parents of children attending nursery schools, 157 completed the questionnaire properly (the completion rate was $48.91 \%$ ). Only the data from clinical examination of children whose parents completed the questionnaire was taken into consideration. Therefore, finally 157 sets of data from clinical examination of children and filled questionnaires by their parents were included in the analysis.

\section{Clinical Examination}

Only one 33 month-old girl had one filling in the first primary left mandibular molar, which represents 3.23\% of the total number of examined patients with caries. Moreover, missing teeth due to caries as well as stainless steel crowns were not observed in the examined population.

Clinical examination showed that 126 children $(80.25 \%)$ were free of dental caries, whereas the other individuals had from 1 to 12 teeth with carious cavities (1-8 teeth in girls and 1-12 teeth in boys; Table 1).

\section{Questionnaire Data}

The questionnaires were filled out by 128 mothers (81.53\% of participants; $76.55 \%$ of mothers of girls and $86.85 \%$ of boys) and 16 fathers $(10.19 ; 14.81$ and $5.26 \%)$ and 13 were filled out by both parents $(8.28 ; 8.64$ and
7.89\%). There was a statistically significant difference between the number of questionnaires completed by mothers and those by fathers $(p<0.0001)$.

Parents were aged from 22 to 48 years (mean \pm SD $33.68 \pm 3.92)$, mothers between the age of 22 and 43 years $(32.72 \pm 3.70)$ and fathers from 25 to 48 years (34.64 \pm $3.90)$.

Most parents had from 1 to 5 either carious or filled teeth $(46.81 \%)$ or extracted teeth due to carious process (63.69\%; Table 1). Only 7 (2.23\%) parents declared that they have teeth without any caries or fillings, while 93 (29.62\%) participants did not have any tooth extractions.

Four $(2.55 \%)$ of the mothers declared that they had teeth without any cavities or fillings; however, 3 of them had anywhere from 1 to 5 extracted teeth. One of these mothers had a child who had 4 teeth (all upper incisors) with caries. Finally, there was one child-mother pair $(0.64 \%)$ with generally healthy teeth, without any carious lesions, fillings or extracted teeth, but there was lack of information in these individuals concerning the dental health status of the father.

Only $104(33.12 \%)$ parents considered their teeth prone to caries (Table 2). In total, 247 (78.66\%) parents declared that they visited the dentist regularly; however, there was statistically significant difference $(p=0.02)$ between mothers (84.71\%) and fathers (72.62\%) (Table 2).

The analysis of mother-father-child triads showed that when the parents visited the dentist regularly, a larger 
Table 3. Data concerning systematic dental visits by the parents and the occurrence of dental caries in children

\begin{tabular}{|c|c|c|c|c|c|}
\hline \multirow{2}{*}{$\begin{array}{l}\text { Mother visits the } \\
\text { dentist systematically }\end{array}$} & \multirow{2}{*}{$\begin{array}{l}\text { Father visits the } \\
\text { dentist systematically }\end{array}$} & \multirow{2}{*}{$\begin{array}{l}\text { Child has } \\
\text { dental caries }\end{array}$} & \multirow{2}{*}{$\frac{n}{157}$} & \multirow{2}{*}{$\frac{(\%)}{(100.00)}$} & \multirow[t]{2}{*}{$p$ value } \\
\hline & & & & & \\
\hline+ & + & + & 21 & $(13.38)^{\mathrm{a}}$ & a vs. $b, p<0.001^{*}$ \\
\hline+ & + & - & 89 & $(56.68)^{b}$ & a vs. $\mathrm{j}, p<0.001^{*}$ \\
\hline+ & - & + & 4 & $(2.55)^{c}$ & a vs. $\mathrm{k}, p=0.33$ \\
\hline+ & - & - & 14 & $(8.92)^{\mathrm{d}}$ & b vs. $\mathrm{j}, p<0.001^{*}$ \\
\hline+ & No answer & + & 2 & $(1.27)^{\mathrm{e}}$ & b vs. $\mathrm{k}, p<0.001^{*}$ \\
\hline+ & No answer & - & 3 & $(1.91)^{\mathrm{f}}$ & c vs. d, $p=0.01^{*}$ \\
\hline No answer & - & - & 1 & $(0.64)^{\mathrm{g}}$ & c vs. h, $p=0.04^{*}$ \\
\hline- & + & + & 0 & $(0.00)^{\mathrm{h}}$ & d vs. I, $p=0.01^{*}$ \\
\hline- & + & - & 4 & $(2.55)^{\mathrm{i}}$ & j vs. $\mathrm{k}, p=0.009^{*}$ \\
\hline- & - & + & 4 & $(2.55)^{\mathrm{j}}$ & h vs. i, $p=0.04^{*}$ \\
\hline- & - & - & 15 & $(9.55)^{\mathrm{k}}$ & \\
\hline
\end{tabular}

+ , person visits the dentist regularly; -, person does not visit the dentist regularly. ${ }^{*}$ Statistically significant $p$ value $(p<0.05)$

percentage of children were free of dental caries (56.68\%), in comparison to those with carious disease (13.38\%) who did not attend dental check-ups as frequently, and the differences were found to be statistically significant $(p<$ 0.001 ; Table 3 ). Additionally, when only the mother visited the dentist regularly, 14 (8.92\%) children did not have carious disease; however, when only the father was attending the dental clinic regularly, the value amounted to $2.55 \%$. The differences were found to be statistically significant $(p=0.01)$.

\section{Discussion}

Oral health of children depends on their caregivers, for they are the ones who are responsible for supervising their children's tooth-brushing and monitoring their eating habits. It is important for them to understand that dental check-ups can help in maintaining good oral health [8].

Positive family functioning and environment promotes the maintenance of proper oral health behaviours, and some tasks (e.g., supervision during tooth brushing or cleaning the child's teeth by the parent or caregiver) are more likely to be carried out systematically on a daily basis [7]. In such families, one may expect that the parents visit the dental clinic regularly and remember about systematic check-ups of their child's teeth. Daly et al. [23] revealed that a mother/father having at least one annual dental professional visit was correlated with having a more positive perception of the ability to maintain their child's oral health.

Dental Health and Oral Care in Polish Mother-Father-Child Triads
Camargo et al. [8] performed a cross-sectional study of 1,129 children at the age of 5 years and found that $37.0 \%$ went to the dentist at least one time, $67.2 \%$ were older than 24 months when they first went to see a dentist, whereas $51.7 \%$ children did not have dental caries. In this study, $84.71 \%$ of mothers and $72.62 \%$ of fathers stated that they attended dental check-ups, whereas only $44.58 \%$ of their children had previously been examined by a dentist.

Moreover, some authors showed that children's routine visits to the dentist and other health habits are much more related to those of the mother than the father, and may be one of the best indicators for measuring the health inequalities in children $[8,24]$. Camargo et al. [8] revealed that children whose mothers reported that they go to the dentist regularly had a 2.5 times higher rate of regular visits than those whose mothers did not visit the dentist regularly. This is in accordance with the current study, where a larger proportion of children whose mothers had regular dental visits, had less dental caries than those of fathers who were systematically examined. It is interesting that data from different countries indicate common observations. Moimaz et al. [25] carried out the survey in 272 Brazilian mothers and their children, aged 1-5 years, concerning their oral health status and social aspects. The authors revealed that the caries history of children with a maternal need for dental treatment was positively associated with a lower family income, lower maternal educational level, infrequent or non-existent visits to the dentist, as well as a higher number of children in the family. However, the caries history of the child was more depen-

Med Princ Pract 2020;29:211-218 
dent on the maternal need for dental treatment than on the social variables since children with or without carious lesions were part of families with closer behaviour. In the Brazilian study, as much as $45.2 \%$ of mothers reported that they had never visited a dental professional, $42.6 \%$ went to the dentist rarely, while $10.3 \%$ only once a year, and only $1.8 \%$ more than once a year. In this study, $78.66 \%$ of parents ( $84.71 \%$ of mothers and $72.62 \%$ of fathers) declared that they visited the dentists systematically, whereas $44.58 \%$ of children, aged between 13 and 42 months, were previously examined by the dentist.

Furthermore, Bridges et al. [26] revealed in the research carried out in a Cantonese population that there was an association between oral health literacy of caregivers and oral health status of their 5-year old children. Some of the parents in the present study were unaware that they should bring their children for regular dental check-ups starting from infancy, as they had never been provided with such information by medical staff.

Many factors affect the frequency of visits to health services, such as the accessibility and availability of service providers, the health needs of the population, as well as other components connected to the organization of the health system [8]. Regular dental check-ups at the nurseries are not covered by the government in Poland. But, it must be emphasized, that all children and adolescents under the age of 18 years, regardless of the employment status of their parents, may be treated by a dentist free of charge. However, it is the duty of the parents to find a dental clinic that provides services financed with public funds, and bring their children for regular dental examination, as well as prophylactic and treatment procedures. In patients, until they complete 18 years of age, free dental prophylaxis and treatment include for example, dental check-ups 4 times a year, including one visit for the purpose of oral hygiene instruction, teeth varnishing every 3 months, fissure sealing in permanent first molars but only once in a tooth in children under the age of 8 years, scaling, treatment of caries in primary and permanent dentition as well as endodontic treatment and so on. Furthermore, adults may have dental check-ups performed free of charge 4 times per year, including one visit for the purpose of oral hygiene instruction. Some other dental procedures are also covered by the National Health Fund (e.g., scaling, treatment of teeth with caries with application of self-curing materials, extractions, etc.).

Currently, in Poland there are no legal regulations obliging carers to visit the dentist with their child. Therefore, there are cases of patients with significant decrements in their oral cavities. According to AAPD defini- tion, "Dental neglect is wilful failure of parent or guardian to seek and follow through with treatment necessary to ensure a level of oral heath essential for adequate function and freedom from pain and infection" [27]. Moreover, Hartung et al. [28] defined that the suspicion on dental neglect occurs when the child has at least 5 untreated teeth because of caries or infection. Numerous teeth with caries $(\geq 6)$ observed in $3.82 \%$ of examined nursery children from Poznan could suggest that there might be such a problem in families. This is evidenced by the presence of teeth with cavities and lack of regular visits at the dental surgery.

In this study, there was only one child-mother pair with generally healthy teeth, that is, without any carious lesion, filling or extracted tooth. As much as $19.75 \%$ of children had dentition with carious changes. In such young nursery age children, one may expect that the percentage of individuals with caries should be much lower, since their teeth are freshly erupted. Tanner et al. [29] examined 192 children (18 pre-dentate and 174 dentate), aged 6-36 months old, as well as their caregivers. The majority of the adults consisted of the children's mothers (81\%), the rest was composed of the fathers (9\%) and other relatives $(4 \%)$ or unrelated persons $(6 \%)$ and caries prevalence (percentage of individuals with dental caries) in those groups varied and amounted to $65,30,71$ and $62 \%$ respectively. In this study, in almost all toddlers, except for one, all teeth that were affected by dental caries were untreated. This is in accordance with the outcome of the study of Camargo et al. [8] who showed that the majority of carious teeth in children examined by the authors were untreated.

Preventive strategies are very important in the case of ECC because they are a much more cost-saving approach in comparison to treatment [17]. Therapy of this disease is mostly surgical and involves restorative treatment, which could be stressful for a child and costly for the family [18]. Without proper education, the recurrence of the disease is common. As much as $40-60 \%$ of children who had conventional surgical treatment of cavities, may develop new lesions within 2 years [30]. Therefore, dental prophylaxis should begin early in the child's life when habitual health behaviours are initiated [7].

It is emphasized that in well-structured health systems, a multi-professional healthcare team should deal with providing information concerning the maintenance of healthy primary dentition [8]. Transmission of data on oral health prophylaxis is not only the dentist's responsibility but also of the other medical professionals who treat children and their parents. Medical staff such as paedia- 
tricians or nurses may be the first professionals who recognize diseases in children. During such visits caregivers have a chance to gain knowledge concerning proper dental habits. The dentist may use professional prophylactic measures in children as well as their parents to protect their teeth against caries process.

\section{Conclusion}

The dental health status as well as oral health care of nursery school children as well as their parents in this study is unsatisfactory. There is a need for an intensive dental educational program focusing on dental prophylaxis for children and their parents. Paediatricians or other medical specialists, such as midwives and nurses, should inform caregivers about the need to visit the dentist regularly. It is beneficial for parents to have knowl- edge concerning proper oral hygiene and dietary habits, as well as bacterial colonization that is responsible for dental caries in a child's mouth.

\section{Acknowledgements}

The authors thank the children who participated in the study, the parents for their informed consent and completion of the questionnaires, as well as the day nursery staff for their help in carrying out the patients' examinations and their assistance in the completion of the questionnaires. We also thank Dr. Marzena Bielas, MD for checking the text for linguistic correctness.

\section{Funding Source}

The research was supported by a grant from the Poznan University of Medical Sciences (502-01-02207319-08716).

\section{References}

1 Fleming E, Afful J. Prevalence of Total and Untreated Dental Caries Among Youth: united States, 2015-2016. NCHS Data Brief. 2018 Apr;307(307):1-8.

2 da Silveira KS, Prado IM, Abreu LG, SerraNegra JM, Auad SM. Association among chronotype, dietary behaviours, and caries experience in Brazilian adolescents: is there a behavioural pattern? Int J Paediatr Dent. 2018 Nov;28(6):608-15.

3 Ravikumar D, R M, Ningthoujam S, Robindro W, R G, Priya V V. Genotypic characterization of Streptococcus mutans in child-mother pair-A PCR based study. J Oral Biol Craniofac Res. 2018 Sep-Dec;8(3):225-30.

4 Llena-Puy MC, Montañana-Llorens C, Forner-Navarro L. Cariogenic oral flora and its relation to dental caries. ASDC J Dent Child. 2000 Jan-Feb;67(1):42-6, 9.

5 Piovesan C, Marquezan M, Kramer PF, Bönecker M, Ardenghi TM. Socioeconomic and clinical factors associated with caregivers' perceptions of children's oral health in Brazil. Community Dent Oral Epidemiol. 2011 Jun; 39(3):260-7.

6 Al Agili DE, Bronstein JM, Greene-McIntyre $\mathrm{M}$. Access and utilization of dental services by Alabama Medicaid-enrolled children: a parent perspective. Pediatr Dent. 2005 Sep-Oct; 27(5):414-21.

7 Duijster D, Verrips GH, van Loveren C. The role of family functioning in childhood dental caries. Community Dent Oral Epidemiol. 2014 Jun;42(3):193-205.
8 Camargo MB, Barros AJ, Frazão P, Matijasevich A, Santos IS, Peres MA, et al. Predictors of dental visits for routine check-ups and for the resolution of problems among preschool children. Rev Saude Publica. 2012 Feb;46(1): 87-97.

9 Saied-Moallemi Z, Virtanen JI, Ghofranipour $\mathrm{F}$, Murtomaa $\mathrm{H}$. Influence of mothers' oral health knowledge and attitudes on their children's dental health. Eur Arch Paediatr Dent. 2008 Jun;9(2):79-83.

10 Wang X, Shaffer JR, Weyant RJ, Cuenco KT, DeSensi RS, Crout R, et al. Genes and their effects on dental caries may differ between primary and permanent dentitions. Caries Res. 2010;44(3):277-84.

11 Gerreth K, Zaorska K, Zabel M, BorysewiczLewicka M, Nowicki M. Association of ENAM gene single nucleotide polymorphisms with dental caries in Polish children. Clin Oral Investig. 2016 Apr;20(3):631-6.

12 Loesche WJ. Role of Streptococcus mutans in human dental decay. Microbiol Rev. 1986 Dec;50(4):353-80.

13 Nara K. Five questions about Streptococcus mutans: theoretical study of its transmission and colonisation. Arch Oral Biol. 2012 Nov; 57(11):1498-511.

14 Policy on Early Childhood Caries (EEC): classifications, consequences, and preventive strategies. A collaborative effort of the American Academy of Pedodontics and the American Academy of Pediatrics. Ref Manual. 2016;40(6):60-2.
15 Alves AC, Nogueira RD, Stipp RN, Pampolini F, Moraes AB, Gonçalves RB, et al. Prospective study of potential sources of Streptococcus mutans transmission in nursery school children. J Med Microbiol. 2009 Apr;58(Pt 4): 476-81.

16 Tedjosasongko U, Kozai K. Initial acquisition and transmission of mutans streptococci in children at day nursery. ASDC J Dent Child. 2002 Sep-Dec;69(3):284-8, 234-5.

17 Azevedo MS, Romano AR, Correa MB, Santos IS, Cenci MS. Evaluation of a feasible educational intervention in preventing early childhood caries. Braz Oral Res. 2015;29(1): 1-8.

18 Albert D, Barracks SZ, Bruzelius E, Ward A Impact of a Web-based intervention on maternal caries transmission and prevention knowledge, and oral health attitudes. Matern Child Health J. 2014 Sep;18(7):1765-71.

19 Journal of Laws No. 45 item 235, Act of 4 February 2011 on care of children under the age of 3 [Dz.U. 2011nr 45 poz. 235]. [ Accessed June 12th, 2019] Available from: http://prawo.sejm.gov.pl.

20 Feldens CA, Giugliani ER, Duncan BB, Drachler ML, Vítolo MR. Long-term effectiveness of a nutritional program in reducing early childhood caries: a randomized trial. Community Dent Oral Epidemiol. 2010 Aug; 38(4):324-32.

21 Barreto SM, Figueiredo RC. Chronic diseases, self-perceived health status and health risk behaviors: gender differences. Rev Saude Publica. 2009 Nov;43 Suppl 2:38-47. 
22 Fontana M, Eckert GJ, Keels MA, Jackson R, Katz BP, Kemper AR, et al. Predicting caries in medical settings: risk factors in diverse infant groups. J Dent Res. 2019 Jan;98(1):68-76.

23 Daly JM, Levy SM, Xu Y, Jackson RD, Eckert GJ, Levy BT, et al. Factors Associated With Parents' Perceptions of Their Infants' Oral Health Care. J Prim Care Community Health. 2016 Jul;7(3):180-7.

24 Vallejos-Sánchez AA, Medina-Solís CE, Minaya-Sánchez M, Villalobos-Rodelo JJ, Márquez-Corona ML, Islas-Granillo $\mathrm{H}$, et al. Maternal characteristics and treatment needs as predictors of dental health services utilisation among Mexican school children. Eur J Paediatr Dent. 2012 Dec;13(4):307-10.
25 Moimaz SA, Fadel CB, Lolli LF, Garbin CA, Garbin AJ, Saliba NA. Social aspects of dental caries in the context of mother-child pairs. J Appl Oral Sci. 2014 Jan-Feb;22(1):73-8.

26 Bridges SM, Parthasarathy DS, Wong HM, Yiu CK, Au TK, McGrath CP. The relationship between caregiver functional oral health literacy and child oral health status. Patient Educ Couns. 2014 Mar;94(3):411-6.

27 merican Academy of Pediatric Dentistry. Definition of dental neglect. [accessed June 1st, 2019]. Available from: "http://www.aapd.org/ policies/".
28 Hartung B, Schaper J, Fischer K, Ritz-Timme S. Care for children with dental neglect: identification of problems and approaches to solving them. Int J Legal Med. 2019 Mar;133(2): 641-50.

29 Tanner AC, Milgrom PM, Kent R Jr, Mokeem SA, Page RC, Liao SI, et al. Similarity of the oral microbiota of pre-school children with that of their caregivers in a population-based study. Oral Microbiol Immunol. 2002 Dec; 17(6):379-87.

30 Berkowitz RJ, Amante A, Kopycka-Kedzierawski DT, Billings RJ, Feng C. Dental caries recurrence following clinical treatment for severe early childhood caries. Pediatr Dent. 2011 Nov-Dec;33(7):510-4. 